\title{
The Aligarh Miracle: A Reappraisal in Context of the Causal Dimensions of Contemporary Social Movement Theories
}

\author{
Hina Khan* \\ Maryam Urooj Khan**
}

\begin{abstract}
Social movements are considered to be a modern phenomenon but they have existed in the past as well. Aligarh movement initiated by Sir Sayyid Ahmed khan is a typical social movement from 19th century, aimed at modernization and uplift of the Muslim community of India. It emerged in a period when the Indian Muslims were facing a sharp decline in their socio-economic and political status. This decline had created a psychology of retreat among them wherein they suspected any attempt to reform their lot. For instance, the introduction of modern education by the British rulers was adopted by the Hindu majority for obvious economic benefits. Conversely, the Muslims remained wary of modern education, particularly the English language as a conspiracy to destroy their age-old culture and religion. In this backdrop Sir Sayyid Ahmed Khan's tireless drive to inculcate modern education proved to be a miracle that transformed the Muslim middle classes for the next century. Although Aligarh movement has attracted tremendous scholarship, there has been virtually little attempt to theorize it as a social movement. In this context the present paper aims to study Aligarh Movement on the parameters of contemporary theories highlighting the causal dimensions of social movements. It will particularly explore the relevance of the elements of deprivation, resource mobilization, political processes, structural strain and those highlighted by the new social movement theory as causal factors in the emergence and evolution of Aligarh Movement.
\end{abstract}

Key Words: Aligarh Movement, Sir Sayyid Ahmed Khan, middle class social movements, deprivation theory, resource mobilization, political processes, structural strain theory, new social movement theory, modernist reform, civil society

\footnotetext{
* Assistant Professor, Department of History, University of Karachi
}

**Research Assistant, Department of History, University of Karachi 


\section{Introduction}

In the nineteenth century, India, like many other regions in Asia and Africa, was engulfed with a wave of transformation. The political scenario of socio-economic decline and defeat contributed widely to the rise of social reform movements. The objectives of those movements ranged from religious revival to social uplift. A number of Hindu, Buddhist and Muslim revivalist movements emerged but with little success. Some others aimed at acculturation - adoption of the positive features of western culture including the modern sciences and education. 1935 marked the year for the introduction of English as the official language in India. Gradually, it became essential for the Indians to learn English in order to continue and advance their careers.

Introduction of modern education and English language seemed as a step to social uplift but it also proved to be a hindrance. It led to the rise of new cleavages in Indian society. The rich and the elite classes ready to adopt and able to afford and attain the new standards of knowledge and skills, achieved more prosperity and power while those who were either unable or reluctant to adopt the new system lagged behind. This division mostly handicapped the Muslim community whose ranks were filled with financially broken and / or intellectually conservative men abhorring and abstaining from the changed standards of education. Aparna Basu points out, "one of the reasons usually assigned for the growth of Muslim separatism has been their educational backwardness. It is commonly accepted that Muslims, less nimble than the Hindus, were less ready to seize the opportunities offered by the western education and less quick to adapt themselves to the changing conditions under the British rule"1

This period marks the emergence of Sayyid Ahmed Khan's (1817-1898) reformist movement aiming at:

- Developing an acceptance and a cultural milieu among the Indian Muslims, favorable to the attainment of modern education, skills and English language. Sir Sayyid asserted that the 'ilm' (knowledge does not only mean religious knowledge or the holy scriptures "word of God" but also the study of various phenomenon taking place in the universe "the work of God" and the two cannot be incompatible with each other. To him modern education was one necessary step for the Indian Muslims in order to earn a respectable position in the changed scenario and omission of that step will leave them overlooked and even eliminated from the political and socio-economic spheres of future India.

- Presenting a rational and non-sectarian version of Islam to the world as well as to the believers.

- Initiating constructive dialogue between Islam and the west and cultivating cordial relations with the western nations particularly with the British. Minimizing the prejudice and animosity between the British Government and the Indian Muslims.

- Convincing the Muslims in particular and Indians in general to adopt the positive features of the modern western civilization without renouncing their own cultural roots.

To attain the above objectives Sir Sayyid's modus operandi was promotion of modern education including religious as well as scientific curricula, which would eventually enlighten the minds of

1 Aparna Basu, The Growth of Education and Political Development in India, 1898-1920 (Delhi: Oxford University press, 1974) 147 
young generations better equipped to participate in modern intellectual discourse and also to compete for government jobs and improve their social and financial position. For this cause he invested time, energy and resources to initiate what was later known as the Aligarh Movement. In this backdrop, the initiation of this movement and its fruition in the form of a number of institutions crowned by the MAO College (later the Aligarh Muslim University) was definitely an uphill task. The very fact that those institutions became the hallmark of Muslim modernism in South Asia and the nurseries of Muslim nationalism in India is sufficient to acknowledge it as a substantially (if not completely) successful social movement.

No doubt, there exist a wide array of scholarly works on the dynamics and achievements of this movement. At present the purpose of this paper is to revisit the causal factors in the initiation and sustenance of Aligarh Movement from the vantage point of various contemporary theories explaining social movements. Accordingly, the paper does not focus on the consequences of the movement nor does it tend to judge the legitimacy of the movement's objectives and methods. It will rather explore the relevance of existing social movement theories with respect to causal factors working in Aligarh Movement. For this purpose the paper is organized in two main sections: the first encompassing an overview of the causal dimensions of various social movement theories; and second, assessing the relevance of those theories in the context of Aligarh Movement.

\section{Section I: Social Movements - Theorizing the Causal Factors}

According to the Encyclopedia Britannica a social movement is 'a loosely organized but sustained campaign in support of a social goal, typically either the implementation or the prevention of a change in society's structure or values'.2 Such movements may vary in size and scope but are essentially collective in nature resulting from a more or less spontaneous coming together of people whose relationships are not defined by rules and procedures but who merely share a common outlook on society. Hence social movements aim at either bringing or resisting a social change. Here it must be noted that the collective behaviors exhibited in crowds in elementary forms (such as milling etc.) or in panic situations are of brief duration guided for the most part by impulse. However, when short lived impulses give way to long-term aims, and when sustained association takes the place of situational groupings of people - the result is a social movement.3 Such movements essentially emerge within civil society and like other groupings they are collectivities with common goals and shared values.

Origins of organized social movements as understood today, can be traced to the 18th century enlightenment era particularly England, USA and France. Since the late 19th century, various researches have been conducted to study social movements theoretically. Over decades, many theories have have surfaced which explain the fundamental circumstances for the emergence of social movements. This section will particularly focus on five theories which tend to explore the causal factors in non-violent reform movements more or less comparable to the Aligarh Movement. These include the deprivation and relative deprivation theories; resource mobilization theory; political process theory; structural strain theory and new social movement theory.

2 Encyclopedia Britannica, "Social Movement", , https://www.britannica.com/topic/social-movement, accessed on 11 june2019 3 Ibid. 


\section{Deprivation and Relative Deprivation}

Deprivation theory suggests that social movements emerge when the masses or certain groups among them feel that they are deprived of their basic needs or public goods which may be abstract such as liberty, autonomy, identity and equality or tangible resources or services such as food, water, education, healthcare, right to vote etc. This sense of deprivation leads the members of the deprived group to come together and articulate their feelings in the form of speech, poetry, fiction, or mass media which soon transforms into articulated suggestions and demands and a line of action to improve the situation and so commences the movement.

This explanation made its way to the theoretical realm by 1960s although its proponents allude to Karl Marx and Alexis D. Tocqueville to support their stand. ${ }^{4}$ By late nineteen-sixties many contemporary social movements were explained in context of deprivation experienced by the respective groups. For instance the Civil Rights Movement in USA was initiated when the nonwhite people perceived that the age-old deprivation of their basic rights can no longer be endured. ${ }^{5}$ The deprivation suffered by a group may be 'absolute' or 'relative' as pointed out by the proponents of this theory. But what actually leads the group to start a social movement is the perception of that deprivation. Many scholars actually see the existence of 'relative deprivation' as rather a stronger factor in a social movement. For instance, Tocqueville studying the French Revolution points out that the French middle classes that became the driving force of the revolution were not 'absolutely deprived' in the ancient regime. ${ }^{6}$ Rather they were earning good fortunes out of trade and other professions. Yet, their social and political status in comparison with the clergy and the nobility (the two upper estates or classes in France) was almost negligible. They paid most of the taxes yet their children, though qualified could not get higher jobs in church, army, bureaucracy or judiciary as those positions were restricted to the upper classes. They had no political power or even say in the affairs of the government. They were more learned and hence more aware of their situation and on behalf of their economic and educational pre-eminence expected to enjoy a better position in the society. Hence, it was their 'relative' and not 'absolute' deprivation that led them through the events of 1789.

The discourse on social movements further developed during 1970s and 1980s though at marked tangents with each other. Gurr in his various writings focused on relative deprivation as a cause of movements using political agitation and violence. ${ }^{7}$ On the other hand, Geschwenders insist that relative deprivation may initiate long sustaining social movements such as the Civil Rights Movement, which may not use violence as a tool. ${ }^{8}$ Nevertheless, the one question that remains unanswered is why the deprivation ignites social movements in some cases while it fails to do so in other? This leads us to explore other factors which might work in the generation as well as sustenance of social movements.

4 Joan Neff Gurney and Kathleen J. Tierney, 'Relative Deprivation and Social Movements: A Critical Look at Twenty Years of Theory and Research', The Sociological Quarterly, 23 (Winter, 1982) 33

5 Barbara N. Geschwender and James A. Geschwender, 'Relative Deprivation and Participation in the Civil Rights Movement', Social Science Quarterly, Vol. 54, No. 2, (September, 1973) 403-411

6 For details Alexis de Tocqueville, The Old Regime and the French Revolution. Stuart Gilbert (trans.). (New York: Doubleday and Company, 1955)

7 Ted Gurr, 'A causal model of civil strife: A comparative analysis using new indices', American Political Science Review (62: 1104-1124) 1968 also Ted Gurr, Why Men Rebel (Princeton: Princeton University Press, 1970) 3-4, 11

8 Geschwender and Geschwender, op.cit. 


\section{Resource Mobilization}

Resource Mobilization Theory suggests that individuals strive to mobilize necessary resources to initiate a social movement in order to counter the grievances faced by them. Such resources may include money, labor, knowledge, skills, social status and the support of influential people such as politicians, industrialists, media personnel etc. 9 These resources play a crucial role in the initiation and sustenance of the movement without which the movement may either not materialize or will not survive for a considerable period. Major proponents of this theory include Lipsky (1968)10, McCarthy and Zald (1977)11, Oberschall (1973)12 and Charles Tilly (1973, 1978 and 1979)13.

McCarthy and Zald question the 'theoretical centrality' of the Deprivation Theory. Informed by the political, sociological and economic theories, they lay emphasis on the variety and extent of resources that 'must be mobilized', connections with 'other groups', and availability of 'external support' for the initiation, sustenance and the eventual success of a social movement. Though mainly focused on leftist social movements in USA, this work presents some very useful insights into the origins of social movements as crucially dependent on the mobilization of necessary resources. McCarthy and Zald viewed social movements as "a set of opinions and beliefs in a population which represents preferences for changing some elements of the social structure and/ or reward distribution of a society" 14 They particularly emphasized the need of an in-depth study of

- An 'aggregation of resources (money and labor)", which they deemed crucial for "engagement in social conflict" (or social movement)

- Existence of "some minimal form of organization

- Involvement of "individuals and organizations from outside the social movement

- A clear, if rudimentary model of supply and demand for a somewhat continued flow of resources to sustain the movement, and

- "Sensitivity to the importance of the costs and rewards" in ensuring the involvement of individuals and organizations in the social movement.

On the other hand, Charles Tilly in his study of 1848 Sicilian Revolution ${ }^{15}$ also asserts that modernization, chiefly in the form of industrialization of Europe had a role, though indirect, in the series of $19^{\text {th }}$ century revolutions. He further elaborated his theory in his 1978-1979 works.

9 Anindya Sen and Omer AVCI, 'Why Social Movements Occur: Theories of Social Movements', The Journal of Knowledge Economy \& Knowledge Management, Volume: XI, No. 1 (SPRING2016) 126

10 Michael Lipsky, 'Protest as a Political Resource'. American Political Science Review, vo. 62 (1968) 1144-1158

11 John D. McCarthy and Meyer N. Zald, Resource Mobilization and Social Movements: A Partial Theory, American Journal of Sociology, Vol. 82, No. 6 (May 1977) 1212-1241, at http//www.jstor.org/stable/2777934 accessed 26 April 2020

12 Anthony Oberschall, Social Conflicts and Social Movements, (Englewood Cliffs NJ: Prentice Hall, 1973) cited in Aldon Morris and Cedric Herring, "Theory and Research in Social Movements - A critical review", Political Behavior Annual, 1984, https://www.researchgate.net/publication/30851820_Theory_and_Research_in_Social_Movements_A_Critical_Review accessed 2 Jan. 2020

13 Charles Tilly, 'Does Modernization Breed Revolution', Comparative Politics, Vol. 5, No. 3 (Special Issue on Revolution and Social Change, 1973) 425-447, at http://www.jstor.org/stable/421272 accessed 20 April, 2020; From Mobilization to Revolution, (Michigan: McGraw Hill, 1978); 'Social Movements and National Politics' CRSO Working Paper No. 197, Ann Arbor, MI, 1979 (Olson 1965)

14 McCarthy and Zald, Op.Cit. 1217-1218;

15 Charles Tilly (1973) Op.Cit. 
Asserting that the concept of social movements is entrenched in "historical time and space", he traces the origin of such movements to the rise of nationalism in $19^{\text {th }}$ century Europe when there was a visible rise of civil society associations including political parties, trade unions and other welfare and rights organizations. Nevertheless, the limited franchise in that period kept a large number of common people outside the election activity and frustrated by the lack of say in political bargaining processes. Tilly defines such movements as "A sustained series of interactions between national power-holders and persons successfully claiming to speak on behalf of a constituency lacking formal representation, in the course of which those persons make publicly-visible demands for changes in the distribution or exercise of power, and back those demands with public demonstrations of support." ${ }^{16}$ Most of the social movements seem to be coherent when viewed from a wider perspective. However, when analyzed from a narrower angle, particularly that of the participants, their fragments and factions become clearer. In such conditions the movement should be studied with a "three-pronged" strategy: first, an investigation into the "response of power holders" towards the movement particularly the vested interests and their capacity to bargain, co-opt, or use force to suppress the movement; second, gauging the capacity of the movement leaders to advance their goals especially "by creating the illusion of unity"; and third, by assessing both the wider and the narrower perspective to trace the dynamics of "collective action". 17

\section{Political Processes}

Making headway in 1980s the proponents of Political Process Theory view social movements in context of the nature and form of the state in which a movement emerges. In case of strong authoritarian and repressive governments the chances of emergence and success of social movements are meager. On the contrary in case of democratic and pluralistic polities, social movements have a better chance to emerge, develop and even succeed. Hence, availability of political opportunities is a necessary precondition for the rise and success of a social movement. Olson (1965) assessing the rational choices of individuals who join a social movement challenged the notions of irrational collective behaviors by questioning the traditional view that social movements are rather abnormal episodes of history showing delinquent and often violent behavior of their actors. ${ }^{18}$ McCarthy and Zald (1973 and 1977) emphasized the importance of resource mobilization in this regard. ${ }^{19}$ Building upon this base, Piven and Cloward (1977) asserted that not just material resources but favorable political and economic conditions also are necessary for a social movement to rise and succeed. For instance, it was only in the periods of "system wide crises, such as the Great Depression" the social movements succeeded extracting concessions from the ruling elites. ${ }^{20}$ Subsequently Tilly (1978) underscored the significance of three components: interests - i.e recognition of possible gains from participation; organization i.e. "level of unified identity and networks"; and opportunity - the strength or weakness of the incumbent political power, in the initiation and success of a social movement.

16 Charles Tilly, (1979), Op.Cit.

17 Ibid, 19-20

18 Mancur Olson, The Logic of Collective Action (Cambridge - MA: Harvard University Press, 1965) cited in Morris and Herring op.cit. (McAdam, McCarthy and Zald, Comparative Perspectives on Social Movements: Political Opportunities, Mobilizing Structures and Cultural Framing 1996)

19 Ibid

20 Francis Piven and Richard Cloward, Poor Peoples' Movement (New York: Pantheon Books, 1977) cited in Morris and Herring Op.Cit. 
Douglas McAdam (1982) presented his research on Black Civil Rights Movement highlighting the role of political opportunities that enabled the movement to articulate the aspirations of the African Americans between 1930 and $1970 .{ }^{21}$ His work clearly demonstrated that the activists in the Civil Rights Movement were political actors making rational choices to achieve common goals, rather than irrational and deviant people acting on mere impulses. He identified three major factors in the rise of the Civil Rights Movement: Political opportunities - i.e. any conducive political and socio-economic conditions, (such as war, migration, industrialization, economic depression etc) which help to target and "undermine the calculations and assumptions on which the political establishment is structured"; strong indigenous organizations, particularly those that pre-existed the social movement among the aggrieved group (such as faith-based or other civil society organizations); and last, a kind of cognitive liberation among the aggrieved group that the "existing political system lacks legitimacy" and a movement against it is likely to bring a "meaningful change". Such recognition creates a degree of empowerment among the group which leads them to get involved in the movement. ${ }^{22}$ Similarly, a decline in the availability of these three factors is likely to cause a decline or even failure of the movement.

Later, by nineties, the concept of cognitive liberation transformed into a two pronged 'framing' of collective recognition among the aggrieved group: a diagnostic frame which enables the group to identify and articulate the grievances faced by it; and a prognostic frame in which the groups endeavors to present a possible and feasible remedy to transform its conditions. ${ }^{23}$

\section{Structural Strain}

The structural strain theory asserts that social movements follow a structural pattern including six essential factors: the deprivation faced by the people or a group of people; recognition of this deprivation; a wide consensus on and articulation of a possible solution; an event which highlights the deprivation and increases the momentum of gathering of the participants and converts it into a movement; a receptive milieu existing among common group members who readily accept the suggested solution; and an eventual mobilization of resources as the movement furthers. $^{24}$

This theory was first proposed by Neil Smelser (1965) in the backdrop of American Civil Rights Movement wherein he identified all the above mentioned six elements which helped in its growth and success. Hence the increasing awareness among the African Americans of their relative deprivation; a recognition by the white liberals of illegitimacy of this deprivation particularly in the context of Cold War in which USA presented itself as a champion of democracy and human rights; the catalyst event of Rosa Parks bus accident; receptive administrations under both Kennedy and Johnson who did not choose to suppress the movement forcefully, and the available monetary, legal, organizational, human and moral resources which

21 Douglas McAdam, Political Process and the Development of Black Insurgency - 1930-1970, (Chicago: University of Chicago Press, 1982) cited in Moris and Herring, Op. Cit. 49-52

22 Ibid, 41

23 D. McAdam, J. McCarthy and M.N. Zald, Comparative Perspectives on Social Movements: Political Opportunities, Mobilizing Structures and Cultural Framing (Cambridge: Cambridge University Press, 1996) 24. (Buechler n.d.) N.B. this theory further evolved to include protest cycles and repertoire of contention but these concepts are not relevant the current study of Aligarh Movement.

24 Sen and AVCI, Op.Cit. 128 
were tapped by the participants to enhance their cause. ${ }^{25}$ In this way, Smelser differed from the classical collective behavior theorists in two ways: first, by asserting that social movements were not just a result of abnormal or deviant behavior of certain groups but are rather result of some identifiable structural features; second, by putting together the elements of deprivation, resource mobilization and political processes as structural elements in the origin of a social movement. However, his main focus remains on the prevailing tension within the existing system which he calls 'structural strain' which actually initiates a movement while the other factors assist the participants in furthering their goals.

\section{New Social Movements}

By 1980s emergence of new social movements in Europe, particularly those resisting the Soviet Satellite states in East Europe led to a fresh appraisal of theories explaining the causal factors in social movements. A number of scholars set upon revisiting the hitherto most popular explanations of class conflict and mobilization of deprived groups and brought forth some other factors as pivotal in social movements. The new explanations though not homogeneous but considerably varied, can be categorized as follows:

\section{Political Version}

It focuses on state actions as a stimulant of social activism. Mainly adopted by neo-Marxists this version identifies "the social formation of advanced capitalism" as instrumental in the rise of "New Social Movements". ${ }^{26}$ Nevertheless it recognizes the significance of "identity formation, grievance definition, and interest articulation. While admitting the existence and potential of class-based movements the proponents of this version also identify socio-cultural factors such as race, gender, nationality and ethnic identity as mobilizing agents in a social movement. For instance, Alain Touraine in 1981 asserted that post-industrial societies harbor a "central conflict" that essentially involves the state. The increased knowledge and technology leads to a perpetual struggle between "the dominant class of managers and technocrats and the popular class of consumers and clients to assume self management in the society. ${ }^{27}$

Further, in 1983 Manuel Castells highlighted the existing conflict between the dominating capitalist system and bureaucratized social order and the urban social movements demanding political autonomy, de-commoditization of collective consumption and recognition of community identity and local culture. ${ }^{28}$ Without rejecting the role of conventional working class activism, he recommends the new social movements to play an instrumental role to push the state for adopting policies to fulfill above mentioned demands.

25 N. J. Smelser, Theory of collective behavior. (New York: Free Press, 1965), cited in Morris and Herring, op.cit 17-22

26 Stephen M. Buechler, "New Social Movements and New Social Movement Theory" in Wiley-Blackwell Encyclopedia of Social and Political Movements, https://www.researchgate.net/publication/277702338_New_Social_Movements_and_New_Social_Movement_Theory accessed 13 June 2020

27 Alaine Touraine, The Voice and the Eye - An Analysis of Social Movements, (English translation by Alan Duff) (New York: Cambridge University Press, 1981) cited in Buechler op.cit.

28 M. Castells, The City and the Grassroots, (Berkley: University of California Press, 1983) cited in Buechler, op.cit 


\section{Cultural Version}

It focuses on cultural patterns in a society and is more disposed towards "everyday life, civil society and cultivation of free spaces". ${ }^{29}$ According to the proponents of this version, social movements reflect a "defensive reaction" against a dominant group or authority rather than a simplistic manifestation of class conflict. They also reject the idea that their (cultural) version is "apolitical" as assert that at times of stress cultural identities play a more political role to challenge the existing order. In 1987 Jurgen Habermas in his elaborated theory of the modern social structure identified two distinct and conflicting spheres: one, "the politico-economic system governed by generalized media of power and money" which by virtue of its position possesses "instrumental rationality"; the other, "a lifeworld organized through normative consensus". In this struggle, the "lifeworld retains a communicative rationality" (vis-à-vis the instrumental rationality of capitalist state) requiring that norms be justified through rational discourse". In this setup, Habermas views the New Social Movements as defenders of the autonomy and communicative rationality of the lifeworld. ${ }^{30}$

Another proponent of cultural version Alberto Melucci in 1996 views processing of information at the center of power in modern complex societies. Consequently, the New Social Movements entail collective action to control information production and symbolic resources. "Movements that challenge prevailing cultural codes strike directly at this new form of power". The complexity of modern society is also reflected in the cleavages with traditional bases of identity such as "religion, neighborhoods, parties or classes". ${ }^{31}$

In this context, Buechler identifies eight "common cercerns" in the various new social movement theories ${ }^{32}$ :

1. Recognition of the historical role of a distinct social formation (race, community, ethnicity, gender etc) that forms the basis for the rise of a social movement

2. New social movements emerge as "direct responses to post-industrialism, late modernity, advanced capitalism or post-modernity" what Habermas calls the "colonization" of human spaces by bureaucratic states, capitalist markets, comodified cultures and scientized relationships.

3. New social movements rise from a diffuse and more complex base. They are not rooted (or are just partially rooted) in the class structure but in other factors such as race, ethnicity, gender, sexual orientation etc.

4. The people are more likely to engage in a social movement if they are more able to define their collective identity. Hence construction of a collective identity becomes essential for the rise of a social movement.

5. With the overwhelming industrialization and advancement of "invasive technologies", the distinction between private and public has blurred. In such conditions social movements are not just a response to the politicization of everyday life but also a cause of this politicization.

29 Ibid

30 Habermas, The Theory of Communicative Action, vol 2 (Boston: Beacon, 1987) cited in ibid.

31A. Melucci, Challenging Codes (Cambridge: Cambridge University Press, 1996) cited in ibid

32 Steven M. Beuchler, Op.Cit. 
6. Taking a tangent from the materialist/ Marxist paradigm, the new social movements strive not for quantity but quality of life. Rather than seeking power or hegemony, they struggle for democracy, autonomy and identity.

7. New social movements involve rather unconventional goals and methods. Their ideologies often include a "philosophical or spiritual rejection of the instrumental rationality of advanced capitalist society and its system of social control and cooptation".

8. The New Social Movements usually show a preference for decentralized, egalitarian, participatory and mostly ad hoc organizational forms as these movements organization is less important when compared to movement values and membership identities. In Melucci's words, New Social Movements "function less as standing armies than cultural laboratories that vacillate between latency and visibility"

On the basis of the above discussed theories of social movements the next section will explore the relevance of these theories to the Aligarh Movement of nineteenth century India.

\section{Section 2: Aligarh as a Social Movement}

It is obvious that the theoretical literature on social movements mainly developed in the midtwentieth century particularly in USA and Europe. How far a movement of late $19^{\text {th }}$ century South Asia can be explained by those theories is a critical question. Nevertheless, Aligarh Movement has attracted a wide range of scholarship in the East and the West. Most of the scholars have recognized it definitely as a social movement just like the Jadeed Movement in the Muslim regions of Russian Empire. ${ }^{33}$ For instance, GFI Graham's Life and Work of Sayyid Ahmed Khan that counts as a primary source on the topic quotes several contemporary dignitaries and scholars recognizing and praising Sir Sayyid's work as a "movement that would live in history". ${ }^{34}$ Under the staunch leadership of Sir Sayyid Ahmed Khan, Aligarh Movement definitely played an exceptional role in the historical transformation of the Muslim community of Indo-Pakistan sub-continent with its particular focus on modern education and sciences. Therefore, for the social scientists working on social movements in South Asia, it is imperative to look at the origins and nature of this movement from the prism of social movement theories.

Aligarh movement fits the general definition of a social movement as "a loosely organized but sustained campaign in support of a social goal", or "... socially shared activities and beliefs directed towards a demand for change in some aspect of the social order". 35 Such "shared activities" may employ a central organization and leadership around which the participants rally for the achievement of a set of goals. In Aligarh Movement a sustained campaign to convince the middle class and upper middle class Muslims of India to acquire modern English education became the 'social goal' in the changed socio-political scenario of post-Mutiny (1857-1858) era. The personality of Sir Sayyid Ahmed Khan (1817-1998) along with his staunch companions provided the central leadership and the MAO College Aligarh became the central organization in this struggle. However, as this paper is particularly focused on the causal factors in a social

33 See Hina Khan, 'Sir Sayyid and Gasprinsky - A Comparative Study of two Modernist Civil Society Movements in India and Russia, Historicus - Quarterly Journal of Pakistan Historical Society, Vol. LXIII, No. 3, (July-September, 2015)

34 G.F.I. Graham, The Life and Work of Sayyid Ahmed Khan, (Edinburgh and London: William Blackwood and Sons, 1885) 286.

35 Joseph R. Gusfield, ed., Protest, Reform and Revolt: A Reader in Social Movements (New York: Wiley, 1970), 2. 
movement, it is desirable to analyze the causal factors in Aligarh Movement in the light of the theories discussed in previous section:

\section{Deprivation or Relative Deprivation}

It is historically correct that the post-1857 Muslim Community of India was in dejected conditions. Many of the Muslims were directly affected by the consequences of the aborted Mutiny. Muslim upper and middle classes felt displaced under the changed political and social scenario. British became the paramount power in India which was now directly controlled by the British Crown. Uprooted from power the Muslim elites particularly faced the shock with a defeatist attitude. Deprivation was wide-spread in India but it particularly hit the Muslim community. The introduction of modern utilitarian brand of education to the natives with English as a preferred medium of instruction changed the socio-economic status of the Indian intelligentsia. Particularly the Muslim educated classes well versed in Arabic, Persian and native knowledge, were rendered 'illiterate' as they lacked proficiency in English language. Deprivation was bound to set in. Economic decline was accompanied with a social degradation and helplessness. Pride and prejudice precluded the Muslims from adopting the new standards of learning and efficiency. ${ }^{36}$ On the other hand, the majority Hindu community, though equally backward and unstable, proved to be quicker and smarter to adopt the modern education and hence availed the newly opened opportunities in jobs and business. ${ }^{37}$ This led the Indian Muslims, particularly the upper and upper middle classes known as ashrafia who were displaced from power, to perceive a kind of relative deprivation as compared to the gradually prospering Hindu community. Hence in this scenario, the economic prosperity through respectable employment was perceived by the Muslims as a 'public good' being denied to them because of their inability and reluctance to acquire modern education and proficiency in English language.

In this backdrop, Sayyid Ahmed Khan emerged as the farsighted leader who not only diagnosed this relative deprivation but also its basic cause namely Muslim abhorrence and indifference towards modern education and English language. His remedy was to convince the Muslims, particularly the ashrafia to come out of their ignorance and adapt themselves to the changing conditions in which modern western education and languages will be their major tools to achieve socio-economic stability. This sense of deprivation led a group among Muslim ashrafia to come together under the banner of Sayyid Ahmed and so a social movement was born. Speeches, writings and public meetings of Sayyid Ahmed conveyed his message to his target group meanwhile he chalked out a concrete plan to establish institutions to fulfill his goals. As early as 1858, he had inaugurated a school at Muradabad especially for the study of modern history. In 1862 foundation of a Society to translate useful books from other languages to Urdu aimed to acquaint Muslims with modern knowledge of sciences and history. At the inaugural session of the Society he stated, "I am strongly in favor of disseminating knowledge of History, ancient and modern, for the improvement of my fellow countrymen". ${ }^{38}$ This society later transformed into the well-known Scientific Society, Aligarh with a library and a Journal called Aligarh Institute

\footnotetext{
36 Altaf Hussain Hali, a religious scholar and a contemporary and biographer of Sir Sayyid, called the English schools "majhalay" meaning adobes of ignorance. Hafiz Malik, Sir Sayyid Ahmed Khan and Muslim Modernization in India and Pakistan, (New York: Columbia University Press, 1980) 51

37 Propensity of Hindu community towards adopting modern education can be attributed to the reform movements particularly Ram Mohan Roy's Brahmo Samaj which had a deep impact in modernization of Hindu Community.

38 Prof, Shan Muhammad, The Aligarh Movement: Basic Documents 1864-1898 (Lahore: Allied Books, 1986) xi
} 
Gazette. Apart from a collection of books the Society subscribed to more than forty journals and other periodicals of which about eighteen were in English and others in Persian, Arabic, Sanskrit, Urdu etc. The journey soon developed as a movement with the foundation of Mohammedan Anglo-Oriental College at Aligarh in 1776. All India Mohammedan Educational Conference was founded in 1886 to deliberate upon the educational requirements of Muslims and the progress towards introduction of western education. These efforts were accompanied with a wide range of writings from Sir Sayyid and his colleagues which not only created awareness and understanding of possible ways to resolve educational and socio-economic problems of Muslims but also countered the criticism of opponents in a scholarly manner.

Here one major question arises that even with a clear perception of deprivation, was it possible for Sir Sayyid and his followers to initiate such a grand project in face of serious social and financial hurdles and severe opposition from within Muslim community? This question leads us to probe into the obvious success in resource mobilization which made it possible.

\section{Resource Mobilization}

Individuals strive to mobilize necessary resources to initiate a social movement in order to counter the grievances. This theory highlights the "assets and capacities of aggrieved groups to explain the rise, development and outcome of social movements. ${ }^{39}$ Such resources may be categorized as human, material, financial, and organizational resources including the support from other groups, media, government officials etc. "Organizations must deliberately mobilize for collective action to capitalize on such grievances. ${ }^{40}$ In this context, Sir Sayyid's success in initiation, continuation and eventual success of Aligarh Movement can be studied in the light of his ability to mobilize all available resources.

Driven by his own sincere understanding of the grievances of Indian Muslims, Sir Sayyid's grand remedial plan could not have seen the daylight without availability of durable resources. Himself hailing from a well-to-do and respectable family of Delhi with good connections with Mughal Court and the English officials, and later being in English service, Sir Sayyid had little to be worried for his and his family's livelihood. ${ }^{41}$ However, to initiate a movement all kinds of resources were needed. Since his "first attempt at education" - the foundation of Moradabad school (1858), Sir Sayyid and his comrades had been exploring the various avenues for moral, administrative and financial support. In Graham's own words at the inaugural of the Translation Society, "... it will be through the modern arts and sciences that this country is to advance with the age, I am sure that those interested in India's well being will give their hearty aid to this society". ${ }^{42}$ Just after his return from England in late 1870, Sir Sayyid commenced a vigorous fund raising campaign for the establishment of the college of his dream - a non-government institution for the education of Indians and especially Indian Muslims. 'A Committee for the better diffusion and advancement of learning among Mohameddans of India' was formed with some enlightened Muslims to explore the reasons behind Muslim community's inhibitions against the state-backed education. This committee, though became controversial because of its

39 J.C. Jenkins, National Encyclopedia of Social and Behavioral Sciences, 2001, at https://www.sciencedirect.com/topics/socialsciences/resource-mobilization, accessed 23 April, 2020

40 David S. Mason, 'Solidarity as a Social Movement', Political Science Quarterly, Vol. 104, No. 1, (1989) 44

41 GFI Graham, Op.Cit. 1-8

42 Ibid, 73 
radical ideas, br (Mason 1989)ought a tremendous human resource to Sir Sayyid in his mission. Later the committee was renamed as MAO College Funds Committee to raise funds for the proposed college. Among the substantial patrons of the College were wealthy aristocrats of India including Mahraja of Patiala, Nawab of Rampur, Nizam of Hyderabad, Nawab Salar Jang, premier of Hyderabad, etc. ${ }^{43}$ With reference to religious identities, Sir Sayyid's was equally as pluralistic in his resource mobilization as he was in his disposition with respect to the students and faculty of the College. His mission impressed and attracted a wide array of Muslim, Hindu and Christian patrons his friends Nawab Viqar-ul-Mulk and Nawab Mohsin-ul-Mulk, Mahajas of Banares, and Vizianagaram, Lord Northbrook - the Viceroy of India, and many other dignitaries from all parts of India were patrons and donors of MAO College and later of the movement which generated from it. Never was Sayyid Ahmed shy to adopt fundraising activities from personal requests to public collections even "agreeing to dance in a state fair".44

Apart from this, various nonprofit and voluntary societies, and residents of various cities collected and donated money for the cause of Aligarh Movement.45 Sir Sayyid's connections with the British Government and local dignitaries brought a wide range of official facilitation, human resource and skilled personnel to the movement. His own team of learned compatriots carried the movement efficiently during his lifetime and even after his death in 1898.

So apart from a sense of deprivation, availability of necessary resources and ability of the movement's leadership to harness those resources in the fulfillment of the cause of the movement also played a vital role in the rise and success of the Aligarh Movement. However, as asserted by Piven and Cloward, not just material resources but suitable political and economic milieu is also vital for the rise of a social movement. This brings us to the Political Process theory of social movements.

\section{Political Processes}

When viewed from the prism of the 'nature and form of the state', the Aligarh Movement at least to some extent acquiesces with the Political Process Theory. Its true that the British Government of India was as strong and authoritarian as any colonial government, yet the post-mutiny conditions of India allowed for the rise of a number of social movements across the country. The ferocity of the events of 1857 had led to "system-wide crises" which compelled the British thinkers and officials to probe into their own shortcomings and failures to understand the rising sentiment against them. In this backdrop surfaced those political opportunities which provided a conducive environment for the rise of social movements of course those which had no direct confrontation with the government. Hence, other reform and revivalist movements such as Brahmo Samaj and Arya Samaj also availed this opportunity and found fertile grounds for their activities. Far from being irrational and violent collective behavior, these movements rather reflected the rational choice of participants and leadership in striving to bring a meaningful change in their target communities.

43 Ibid, 245-258

44 Yasmin Saikia and M. Raisur Rehman (eds.), The Cambridge Companion to Sayyid Ahmed Khan, (Cambridge and New York: Cambridge University Press, 2019) 10; also see Graham, op.cit. 272-273 (S. A. Khan 1958)

45 Graham, op. cit. 345-349 
After the establishment of Scientific Society, Aligarh Movement gained staunch adherents who trusted in Sir Sayyid and recognized the potential gains that could be accrued through participation. MAO College provided a central organization for the realization of the movement's goals. And lastly, the post-Mutiny political scenario presented a set of opportunities for the movement to take off. Hence the three necessary conditions identified by Tilly were more or less fulfilled. However, the movement (just like the Brahmo Samaj etc) never challenged the legitimacy of the British Government, but rather hoped to dispel the previous misunderstandings and cultivate better relations with the government so as to extract concessions and benefits from the rulers. The cognitive liberation in this case comprised of the a diagnostic frame wherein the Muslims, especially their upper and upper middle classes led by Sir Sayyid perceived the major cause of their deprivation vis-à-vis the Hindu majority of India - the lack of modern education; and a prognostic frame wherein they struggled to achieve a possible and feasible solution as prescribed by Sir Sayyid - attainment of modern education and proficiency in English language to achieve better social and economic position in India.

So now at this point we have found considerable relevance of theories proclaiming relative deprivation, resource mobilization and political processes as causal factors in Aligarh Movement. We can now explore if there exists a certain structural pattern in this case.

\section{Structural Strain}

Smelser's six factors necessary for a social movement to rise are discussed in the following, one by one in the context of Aligarh Movement:

\section{Deprivation}

It has already been established that the Muslim community of India was definitely facing a crushing deprivation glimpses of which can be found from Sir Sayyids's Asbab-e-Baghawat-eHind' (1858)46 and W.W. Hunter's The Indian Musalmans.47 Particularly, Sir Sayyid has pointed out the 'relative deprivation of Muslim upper classes in the pre-1857 period.

\section{Recognition of this Deprivation}

An obvious perception of deprivation suffered by Muslims in general and the upper and upper middle classes in particular, is reflected in various speeches and letters of Sir Sayyid prior to the establishment of MAO College. Particularly the socio-economic deprivation and Muslim failure in acquirement of modern education has been profusely highlighted by Sir Sayyid. 48

\section{An Event That Highlighted the Deprivation and Catalyzed the Movement}

Very obviously, the Indian Mutiny and the following events proved to be a catalyst in the rise of not only Aligarh Movement but many other reform and revivalist movements in India.

46 Sir Sayyid Ahmed Khan, Asbab-e-Baghawat-e-Hind (Urdu), (Aligarh: University Publishers, Muslim University Aligarh, 1958) 119-131

47W.W. Hunter, The Indian Musalmans,(London: Trubner and Co. 1876) 87-129 (Gibb n.d.) (Gibb n.d.)

48For instance see Graham, Op.Cit. 69-70, 72-73 


\section{A Wide Consensus and Articulation of a Possible Solution}

Unfortunately, this requirement could not be expected to be fulfilled in the heterogeneous Indian population in general and the Muslim community in particular. The post-Mutiny shock affected almost all major communities of India. The disappointment in the failure of what is called the 'first war of Indian independence' was traumatic ${ }^{49}$ and the responses to this trauma were understandably heterogeneous. Among the Muslims there were groups who perceived a religious revival as the only way out of the abject decline. Hence a number of reformist-revivalist movements emerged including the Waliullahi Movement which later gave birth to the the Wahabi Movement or Jihad Movement (1820s-1870s). The establishment of Deoband Seminary (1866) from which the Deobandi Movement emanated, reflected another trend of puritanical reformism in Sunni Islam. Sectarian cleavages also remained strong. In presence of such divisions, Sir Sayyid's diagnosis of the cause of Muslim deprivation and his solution to achieve modern education and cultivate cordial relations with the British Government could not be expected to easily gain acceptance and consensus of the Muslim community.

\section{A Receptive Milieu Existing Among the Concerned Group Who Readily Accept the Suggested Solution}

From the beginning Sir Sayyid and his movement met a severe confrontation from many traditional and influential circles among Muslims. The path chosen by Sir Sayyid i.e. modernist reform wherein Islam's "conformity to nature and the laws of science" was highlighted could not be accepted by the Muslim orthodoxy. The very foundation of MAO College as the "first modernist organization in islam, ${ }^{, 50}$ meant to impart religious knowledge along with modern scientific discourse was bound to meet a harsh opposition from orthodox ulama led by those Deoband. He was labeled kafir (infidel), murtad (heretic) and nechari (naturist) so much so that he faced the specter of being killed by his own people. Altaf Hussain Hali, another contemporary and biographer of Sir Sayyid, elaborates that as many as sixty ulama signed fatwas (religious decrees) against him. ${ }^{51}$ In addition, the bitter criticism from Jamaluddin Afghani whose own pupil Mullah Abduh initiated a modernist movement in Egypt was even more discouraging. ${ }^{52}$

Nevertheless, all this opposition could not intimidate Sir Sayyid. He published detailed rejoinders to his detractors in order to explain and clarify his position as well as to assert the significance of modernist reform in Muslim society particularly defending his stance on modern education. ${ }^{53}$ In order to avoid further complications he abstained from teaching himself at the MAO College. He even invited Deoband ulama to prepare the syllabus for the College which the latter refused to do. Sayyid was determined about his mission and sincere about his cause. His liberal and rationalist approach soon began to attract a wide array of emerging Muslim intellectuals who were becoming increasingly aware of the obscurantism prevailing in Muslim

49 The discussion whether the uprising of 1857 should be called 'Mutiny' or 'War of Independence' is outside the scope of this paper.

50 H.A.R. Gibb, Mohammedanism - An Historical Survey (Second Edition) (New York: Oxford University Press, 1962) 181-182

51 Altaf Hussain Hali, Hayat-e-Javed (Urdu), 524-576

52 Gibb, Op.Cit. 181-182

53 Hali, Op.Cit. 537-576 
society of India. Hence the absence of wide acceptance could not halt the movement but in effect instilled more energy into it.

\section{Mobilization of Resources}

As discussed above, Sir Sayyid and his colleagues did not left any avenue unexplored to gather necessary resources including support of the government, Indian aristocracy (of all religions), intelligentsia, and upper middle classes for his mission. This active fundraising and social mobilization played a substantial role in the success of Aligarh Movement.

At this juncture we can finalize our study by looking for any other causal factor which might have proved significant in the rise and success of Aligarh Movement. For this purpose the factors highlighted by the new social movement studies can be assessed.

\section{New Social Movement Theory}

The neo-Marxist notion of "social formation of advanced capitalism" though proposed for the late twentieth century movements, can have a degree of relevance with the $19^{\text {th }}$ century Indian movements also". The establishment of capitalist economy in India under the British rule not only marks the exploitation and repression of the Indian working classes but also inaugurated a utilitarian era of remodeling Indians in the light of Western ideas of civilization. The modernist mission of the modernist state had a deep impact on the socio-cultural environment of India which led to the rise of various revivalist, reformist and later nationalist movements. Those movements rose on the basis of identifying the suppressed position of Indians; defining grievances according to their own perceptions; articulating their targeted goals as well as generating particular identity formation processes which became a basic ground for mobilization of fellow countrymen vis-à-vis the British government. These processes centered on a wide range of identities based on religion, sect, caste, class, ethnicity and eventually Indian nationalism. Initiation of these processes can be identified as one manifestation of what is now called the 'new social movement theory (or theories). Particularly the 'cultural version' of this theory highlighting the 'defensive reaction' vis-à-vis the political authority (here the British Government) and the dominant group (here Hindu majority) seems quite relevant in this case. As described by Habermas, the "instrumental rationality" of the political and economic system established by the state is encountered by the "communicative rationality" of the "life world" of the group identities among the subject population. In case of Aligarh Movement the communicative rationality of the Indian Muslims, though not actually confronted the instrumental authority of the British government, seems to retain grounds by creating a space for the Muslim upper classes in the otherwise hopeless post-1857 scenario. Aligarh was thus able to defend the autonomy and communicative rationality of the life world of Indian society. It is interesting to note that in this case the Aligarh Movement tended not to challenge the government but the prevailing cultural codes of the Muslim society. Insistence on acculturation and adoption of modern ways and modern education directly hit the traditional bases of identity but did motivate a number of enlightened intellectuals to rally around Sir Sayyid and take his mission forward. Common people particularly from upper middle classes saw in Aligarh movement a genuine reformist zeal and supported it to avail the opportunities opened through modern education. 


\section{Towards Conclusion}

Theoretical discourse on social movements is mainly a product of twentieth century. Nevertheless, social movements emerging in various parts of the world are entrenched in history. Most of these movements were initiated and encouraged by the enlightened thought of eighteenth century Europe. However those lofty ideas were never implemented in European colonies. This contradiction created immense confusion among the emerging educated classes of natives of those colonies. On one hand they felt the power of European guns and books. On the other, they felt betrayed of the fruits of European renaissance and enlightenment. In this confusion various ideas were put forward to enable the colonized people to face the challenge of the western onslaught. Modernist reform movements were one response to this onslaught. Aligarh was one of them that transpired in present United Provinces of India and spread to various parts of Northern India including the Muslim majority provinces (Sindh, Punjab, NWPF and Bengal) with its emphasis on modern education and enlightenment thought.

The above discussion shows considerable relevance to Aligarh Movement of theories which underscore deprivation and relative deprivation, resource mobilization, political processes and the structural strains prevailing in society as major factors supporting the cause of the Movement. Muslim displacement from power after the fall of the Mughal Empire did produced alienation, discontent and a widespread sense of deprivation. Further, the pride of the ex-rulers and their prejudice against everything coming from the west kept them from availing the benefits of state-sponsored education introduced in major cities of India. ${ }^{54}$ This repulsion of state education resulted in ineligibility Muslim youth for the state jobs further bringing down their living standards. The perception of this deprivation became severe when seen in comparison to the majority Hindu upper and upper middle classes who were quicker to mould themselves according to the changing situation - hence 'relative deprivation' of Muslims. As asserted by Geshwenders, such relative deprivation helped in initiation of a long-term social movement. ${ }^{55}$ In this scenario, Sir Sayyid's diagnosis and prescribed solution though faced severe opposition from the traditional Muslim circles, proved to be a breath of fresh air for the Muslim youth. This period also saw a visible rise of civil society associations around the world and in India. But the lack of political representation kept the natives outside the political bargaining process and aggravated their sense of deprivation. Aligarh Movement by nature reflects not an irrational and aggressive collective behavior but rather a sustained series of interactions between the power holders and persons like Sir Sayyid who successfully claimed to speak on behalf of the Indian Muslims - the constituency that lacked formal representation under the Brithish Raj. Marxist notions that movements emerge and grow from basic social and economic relations which form the basis of power within a society, clearly points to a class struggle waged by the deprived sections against the power holders, thus reject the idea of an irrational and impulsive collective action and asserts existence of movements with a purposeful line of action under an efficient leadership.

In the case of Aligarh Movement, the role of leadership must not be ignored which takes the burden of awareness creation and also resource mobilization to advance the movement's goals.

54 Sir Sayyid himself has written a lot on the shortcomings of both missionary and government run schools which kept Muslims away from them. For details see Graham, op.cit, 42-43, 246-247

55 Geshwender and Geshwender op.cit, footnote \# 5 
The theories discussed in this paper do not particularly highlight the role of leadership. However, an interesting relevance (though in a different context) appears with Max Weber's study of charismatic movements and charismatic leadership which according to him emerge in "social systems that are undergoing great stress and are unable to meet the needs of a significant number of people" and in such a case leader's own personality and world view becomes a source of attraction for the people to rally around him. Such a movement is born outside the domain of preexisting social organizations, norms and bureaucracies. ${ }^{56}$ This phenomenon though appears analogous to Sir Sayyid and his movement, it takes a clear tangent as according to Weber, it is marked with extreme emotional and ideological (often religious) loyalty of the adherents to the leader and an inherent temporary and unstable nature. Particularly, Weber views this charisma "undiminished, consistent and effective only in statu nascendi" (in nascent or early state). ${ }^{57}$ On the other hand Aligarh Movement though achieved a charismatic tempo and success; it never required or claimed the absolute loyalty of its adherents. Sir Sayyed faced a constant criticism on various aspects of his ideology and modus operandi, not only from the traditionalists but also from his colleagues and co-workers such as Hali. He never abstained to explain his position to his critics. Secondly, the Aligarh movement did transform into an institution (MAO College) with its mundane routines, but it also transformed into a nationalist awareness among the Muslim upper and middle classes. The services of the movement and its center - MAO College, left a lasting impact as it not only succeeded in remodeling a considerable section of Muslim community on modernist and nationalist pattern, ${ }^{58}$ but also made a deep impact on the Muslim thought beyond the borders of India.

56 Max Weber, Economy and Society - An Outline of Interpretive Sociology, edited by Guenther Roth and Claus Wittich, (Berkley: University of California Press, 1968, 1111-1123; Also see Morris and Herring, op.cit. 5 57 Ibid, 1121.

58 Eventually we do see highly capable individuals emerging from Aligarh and participating in India's and Pakistan's freedom movement. 


\section{REFERENCES}

Basu, Aparna. The Growth of Education and Political Development in India, 1898-1920. New Delhi: Oxford University Press, 1974.

Buechler, Stephen M. "New Social Movements and New Social Movement Theory." In WileyBlackwell Encyclopedia of Social and Political Movements. Wiley-Blackwell, n.d.

Castells, M. The City and the Grassroots. Berkley: University of California Press, 1983.

Geschwender, Barbara N., and James A. Geschwender. "Relative Deprivation and Participation in Civil Rights Movement." Social Science Quarterly 54, no. 2 (September 1973): 403-411.

Gibb, H. A.R. n.d.

-. Mohammedanism - An Historical Survey. Vol. Second. 2 vols. New York: Oxford University Press, 1962.

Graham, G. F.I. The Life and Work of Syed Ahmed Khan. Edinburgh and London: William Blackwood and Sons, 1885.

Gurney, Joan Neff, and Kathleen J. Tierney. "Relative Deprivation and Social Movements: A Critical Look at Twenty Years of Theory and Research." The Sociological Quarterly 23 (Winter 1982): 33-47.

Gurr, Ted. "A causal model of civil strife: A comparative analysis using new indices." American Political Science Review 62 (1968): 1104-1124.

—. Why Men Rebel. Princeton - NJ: Princeton University Press, 1970.

Gusfield, Joseph R. Protest, Reform and Revolt: A Reader in Social Movements. New York: Wiley, 1970.

Habermas, J. The Theory of Communicative Action. Vol. 2. Boston: Beacon Publishers, 1987.

Hali, Altaf Hussain. Hayat-e-Javed (Urdu). New Delhi: Silsila-e-Matbuaat-e-Taraqqi-e-Urdu Bureau, 1900.

Hunter, W. W. The Indian Musalmans. London: Trubner and Co., 1876.

Jenkins, J. C. "National Encyclopedia of Social and Behavioral Sciences." 2001.

Khan, Hina. "Sir Sayyid and Gasprinsky: A Comparative Study of Two Modernist Civil Society Movements in India and Russia." Edited by Dr. Ansar Zahid Khan. Historicus - Quarterly Journal of Pakistan Historical Society (Pakistan Historical Society) LXIII, no. 3 (JulySeptember 2015): 33-60. 
Khan, Sayyid Ahmed. Asbab-e-Baghawat-e-Hind (Urdu). Aligarh: University Publishers, Muslim University Aligarh, 1958.

Lipsky, Michael. "Protest as a Political Resource." American Political Science Review 62 (1968): 1144-1158.

Malik, Hafiz. Sir Sayyid Ahmed Khan and Muslim Modernization in India and Pakistan. New York: Columbia University Press, 1980.

Mason, David S. "Solidarity as a Social Movement." Political Science Quarterly 104, no. 1 (1989): 41-58.

McAdam, Douglas. Political Process and the Development of Black Insurgency - 1930-1970. Chicago: University of Chicago Press, 1982.

McAdam, Douglas, J. McCarthy, and M. N. Zald. Comparative Perspectives on Social Movements: Political Opportunities, Mobilizing Structures and Cultural Framing. Cambridge: Cambridge University Press, 1996.

McCarthy, John D., and Meyer n. Zald. "Resource Mobilization and Social Movements: A Partial Theory." American Journal of Sociology 82, no. 6 (May 1977): 1212-1241.

Melucci, A. Challenging Codes. Cambridge: Cambridge University Press, n.d.

Morris, Aldon, and Cedric Herring. "Theory and Research in Social Movements - A Critical Review." Political Behavior Annual, 1984.

Muhammad, Shan. The Aligarh Movement: Basic Documents 1864-1898. Lahore: Allied Books, 1986.

Olson, Mancur. The Logic of Collective Action. Cambridge: Harvard University Press, 1965.

Piven, Francis, and Richard Cloward. Poor Peoples' Movement. New York: Pantheon Books, 1977.

Saikia, Yasmin, and Raisur Rehman. The Cambridge Companion to Sayyid Ahmed Khan. Cambridge and New York: Cambridge University Press, 2019.

Sen, Anindya, and Omer AVCI. "Why Social Movements Occur: Theories of Social Movements." The Journal of Knowledge Economy and Knowledge Management XI (Spring), no. 1 (2016): 125-130.

Sen, Anindya, and Omer AVCI. "'Why Social Movements Occur: Theories of Social Movements." The Journal of Knowledge Economy and Knowledge Management XI, no. I (Spring 2016): 125-130. 
Smelser, N. J. Theory of Collective Behavior. New York: Free Press, 1965.

"Social Movement." Encyclopedia Britannica. n.d. https://www.britannica.com/topin/socialmovement (accessed June 11, 2019).

Tilly, Charles. "Does Modernization Breed Revolution." Comparative Politics 5, no. 3 (Special issue on Revolution and Social Change (1973): 425-447.

—. From Mobilization to Revolution. Michigan: McGraw Hill, 1978.

—. "Social Movements and National Politics." CRSO Working Paper No. 197. 1979.

Tocqueville, Alexis de. Old Regime and the French Revolution. Translated by Stuart Gilbert. New York: Doubleday and Company, 1955.

Touraine, Alain. The Voice and the Eye - An Analysis of Social Movements. New York: Cambridge University Press, 1981.

Weber, Max. Economy and Society - An Outline of Interpretive Sociology. Edited by Guenther Roth, \& Claus Wittich. Vol. 2. 2 vols. Berkley: University of California Press, 1968. 
The Aligarh Miracle: A Reappraisal in Context of the Causal Dimensions of Contemporary Social Movement Theories 